\title{
OPEN Mercury deposition in Western Tethys during the Carnian Pluvial Episode (Late Triassic)
}

\author{
Mina Mazaheri-Johari ${ }^{1 凶}$, Piero Gianolla ${ }^{1}$, Tamsin A. Mather ${ }^{2}$, Joost Frieling ${ }^{2}$, Daoliang $\mathrm{Chu}^{3}$ \& \\ Jacopo Dal Corso ${ }^{3 凶}$
}

The Late Triassic Carnian Pluvial Episode (CPE) was a time of biological turnover and environmental perturbations. Within the CPE interval, C-isotope and sedimentary records indicate multiple pulses of depleted carbon into the atmosphere-ocean system linked to discrete enhancements of the hydrological cycle. Data suggest a similar cascade of events to other extinctions, including being potentially driven by emplacement of a large igneous province (LIP). The age of the Wrangellia LIP overlaps that of the CPE, but a direct link between volcanism and the pulsed CPE remains elusive. We present sedimentary $\mathrm{Hg}$ concentrations from Western Tethys successions to investigate volcanic activity through the previously established CPE global negative C-isotope excursions (NCIEs). Higher $\mathrm{Hg}$ concentrations and $\mathrm{Hg} / \mathrm{TOC}$ are recorded just before and during NClEs and siliciclastic inputs. The depositional settings suggest volcanic $\mathrm{Hg}$ inputs into the basins over the $\mathrm{NCIEs}$ rather than increases of $\mathrm{Hg}$ drawdown or riverine transport. Differences in $\mathrm{Hg}$ and $\mathrm{Hg} / \mathrm{TOC}$ signals between the basins might be linked to coeval LIP style or the temporal resolution of the sedimentary successions. Overall, our new data provide support for a link between pulses of Wrangellia LIP volcanism, NCIEs, and humid phases that mark the CPE in the Western Tethys.

The Carnian Pluvial Episode (CPE, Late Triassic) was an interval of global warming and enhanced hydrological cycle coupled to extinctions and major radiations among terrestrial and marine taxa, giving rise to new modernstyle ecosystems ${ }^{1-11}$. The CPE lasted for 1.2-1.6 Myrs, in the late Julian-early Tuvalian of the Carnian ${ }^{12-14}$ (Fig. 1), and was marked by repeated carbon-cycle perturbations, as evidenced by multiple negative carbon-isotope excursions (NCIEs) ${ }^{6-8,13,15-22}$. The NCIEs indicate large injections of ${ }^{13} \mathrm{C}$-depleted carbon into the exogenic C-cycle reservoirs, each of which just precedes increases of continental runoff, as chiefly observed in the successions of the Western Tethys, and changes in carbonate sedimentation ${ }^{7,8,21,23,24}$. Understanding the triggers of the CPE is crucial given its important juncture in Earth history and the parallels with the cascade of events associated with other mass extinctions. Coeval volcanic activity has previously been invoked as a cause for the CPE's NCIEs, both in terms of direct $\mathrm{C}$ emissions and as a trigger for positive $\mathrm{C}$-cycle feedbacks (e.g., release of ${ }^{13} \mathrm{C}$-depleted $\mathrm{C}$ from ocean floor clathrates) ${ }^{6,13,17}$. The emplacement of the Wrangellia oceanic plateau, a submarine large igneous province (LIP), has been the main candidate for this scenario ${ }^{6,8,9,15-18}$. However, besides age overlap ${ }^{25}$ and Os isotope data from deep water successions of Panthalassa that show Wrangellia started in the Early Carnian Trachyceras ammonoid Zone, hereafter referred to as Julian $1^{16}$, further evidence for volcanic activity in the sedimentary record has been lacking. Hence, a direct temporal link between LIP volcanism and the environmental changes has been difficult to substantiate. Sedimentary $\mathrm{Hg}$ concentrations have been used to track volcanic activity during intervals of mass extinction and global environmental change ${ }^{26-29}$. Though other factors can at least partially control $\mathrm{Hg}$ deposition in terrestrial and marine settings ${ }^{30,31}$, increases of sedimentary $\mathrm{Hg}$ concentration at or directly below the level of mass extinction, $\mathrm{C}$-cycle and/or environmental perturbations have been used as evidence for the influence of volcanism ${ }^{28}$. Here we analysed $\mathrm{Hg}$ and total organic carbon (TOC) concentrations in four Carnian marine sedimentary sequences of the Western Tethys to evaluate whether enhanced Hg loading and volcanic activity coincided with the $\mathrm{C}$-cycle and hydrological perturbations across the CPE.

\footnotetext{
${ }^{1}$ Department of Physics and Earth Sciences, University of Ferrara, Ferrara, Italy. ${ }^{2}$ Department of Earth Sciences, University of Oxford, South Parks Road, Oxford, UK. ${ }^{3}$ State Key Laboratory of Biogeology and Environmental Geology, School of Earth Sciences, China University of Geosciences, Wuhan, China. ${ }^{\bowtie}$ email: mzhmni@unife.it; j.dalcorso@cug.edu.cn
} 


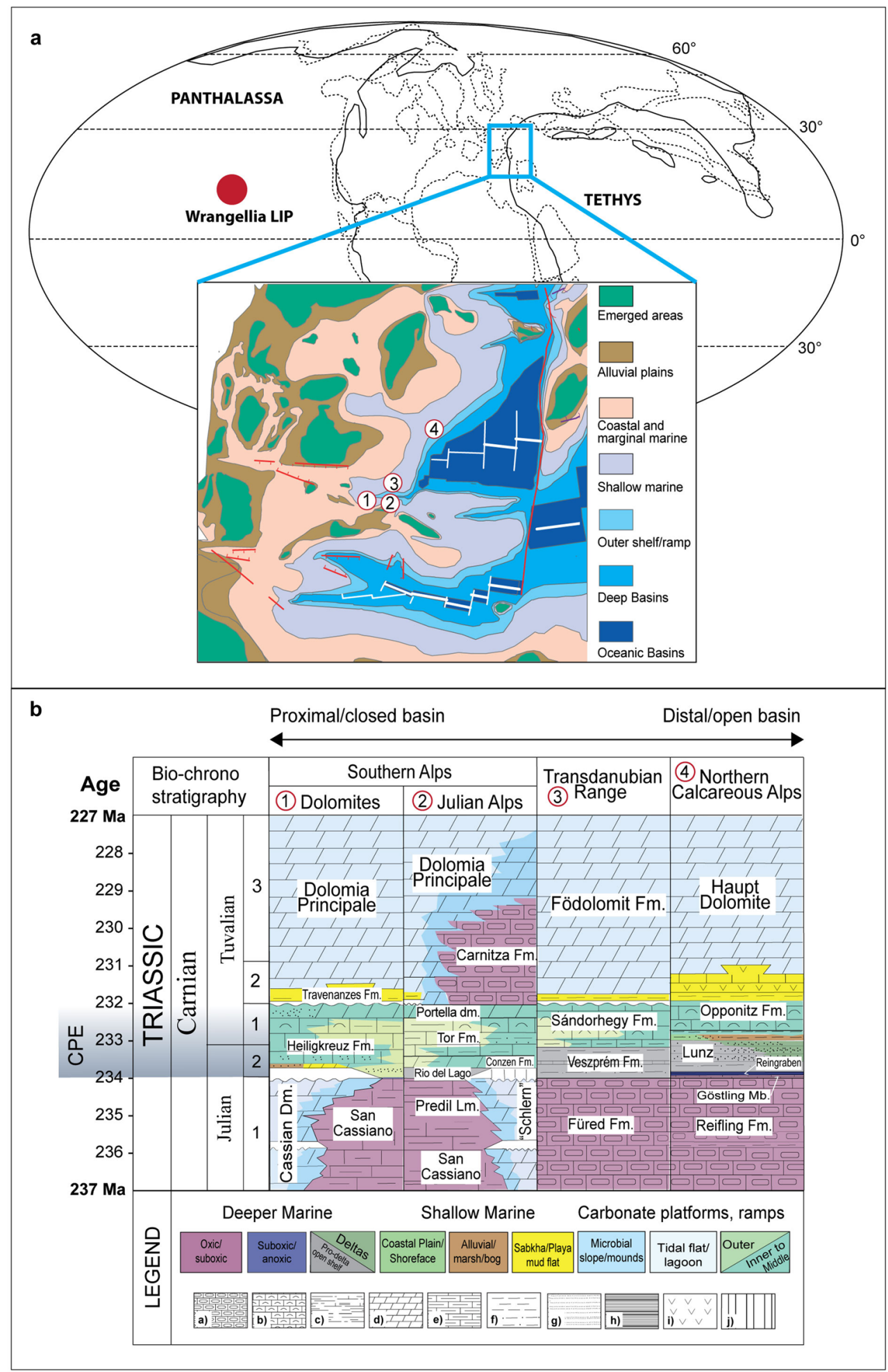

Figure 1. (a) Late Triassic palaeogeography and position of the studied successions in the Western Tethys ( 1 =Dolomites; 2 = Julian Alps; 3 = Transdanubian Range; 4 = Northern Calcareous Alps); the map is modified using QGIS (version 3.20.1, https://qgis.org/en) after ref. ${ }^{14}$, (b) Lithostratigraphic scheme for the Carnian formations in the studied areas. Julian $1=$ Trachyceras zone, Julian 2=Austrotrachyceras austriacum zone; Tuvalian $1=$ Tropites dilleri zone, Tuvalian 2 = Tropites subbullatus zone, Tuvalian $3=$ Anatropites spinosus zone. Lithology: $\mathrm{a}=$ Cherty limestone, $\mathrm{b}=$ Bioclastic limestone, $\mathrm{c}=$ Limy marlstone, $\mathrm{d}=$ Dolomite, $\mathrm{e}=$ Marly limestone, $\mathrm{f}=$ Siltstone, $\mathrm{g}=$ Sandstone, $\mathrm{h}=$ Black shale, $\mathrm{i}=$ Evaporites, $\mathrm{j}=$ Hiatus. 

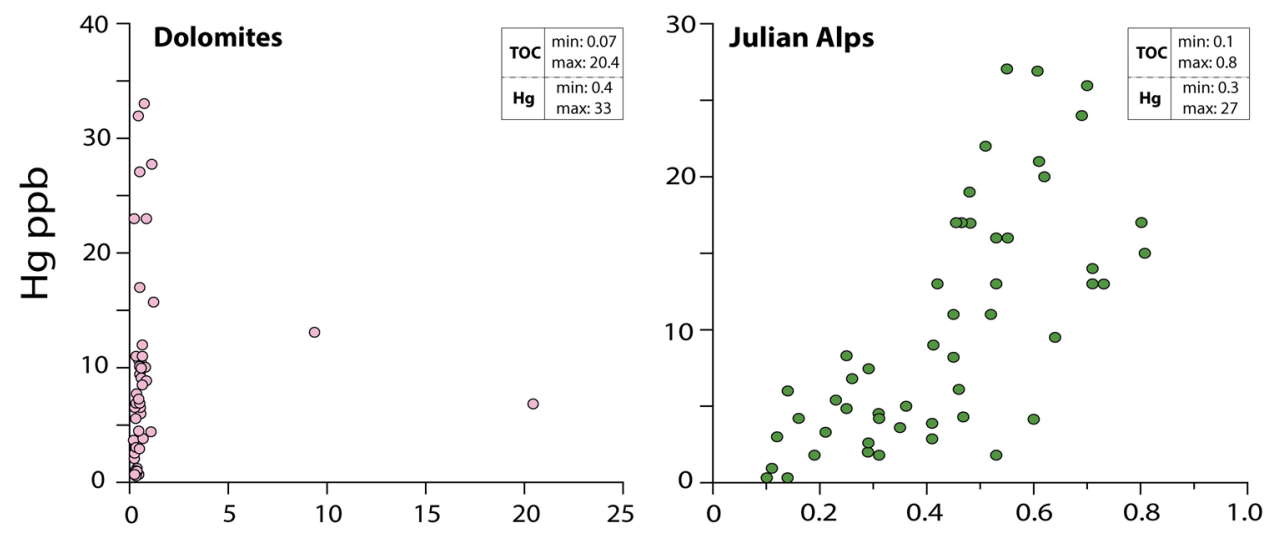

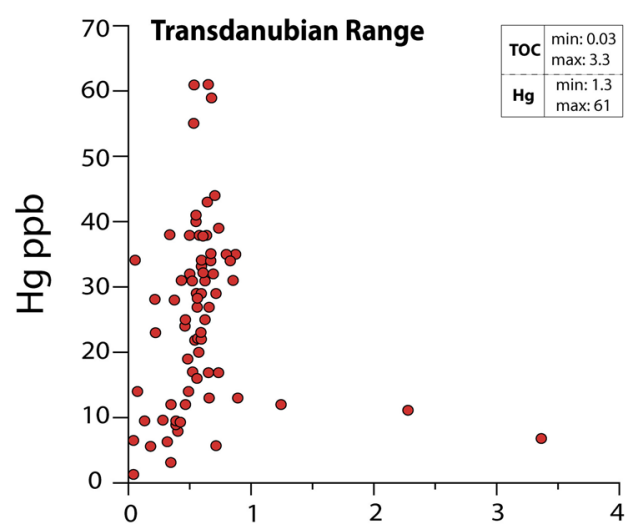

TOC wt $\%$

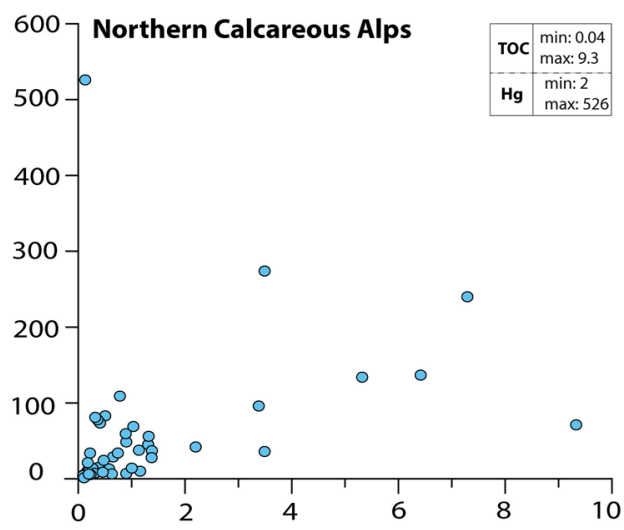

TOC wt $\%$

Figure 2. Hg vs TOC values from the studied successions of the Western Tethys (Fig. 1).

\section{Study area}

We analyzed 243 mudstone and shale samples for $\mathrm{Hg}$ and TOC from 4 different areas of the Western Tethys realm: Southern Alps (Dolomites and Julian Alps) in Italy, Northern Calcareous Alps (Lunz) in Austria, and Transdanubian Range (Balaton) in Hungary (Fig. 1). The studied successions encompass the CPE and are wellcalibrated with ammonoid, conodont, and sporomorph biostratigraphy ${ }^{7,8,32}$. In the Dolomites, 20 samples are from the Milieres section and 30 samples from the Heiligkreuz section, encompassing the Heiligkreuz Formation (A. austriacum-T. dilleri ammonoid zones = Julian 2-Tuvalian 1$)^{7,8}$. In the Julian Alps, 58 samples were collected at Cave del Predil (Rio Conzen and Rio delle Cascate sections). The succession encompasses the Predil Limestone, the Rio del Lago Formation, the Conzen Formation, and part of the Tor Formation (Trachyceras-A. austriacum zones $=$ Julian 1-2) ${ }^{8,32}$. In the Transdanubian Range, a total number of 73 samples were analyzed from two cores (BFÜ-1 and MET-1; Rostási et al., 2011). 39 samples are from BFÜ-1 and 34 samples from MET-1, covering the Füred Limestone and the Veszprém Marl Formation (Trachyceras-A. austriacum). In the Northern Calcareous Alps (Austria), we analyzed 62 samples from Steinbach and Polzberg sections ${ }^{7,19}$, encompassing the Reifling Formation, the Göstling Member and the Reingraben Formation (Trachyceras - A. austriacum zone = Julian 1-2). A detailed description of the studied successions is in the Supplementary Information.

\section{Results}

In the studied sections of the Western Tethys, the measured Hg concentrations are $<100 \mathrm{ppb}$, except those of the Northern Calcareous Alps which included the highest values (up to $526 \mathrm{ppb}$ ) (Figs. 2, 3). The average Hg concentration ( $29 \mathrm{ppb}$ ) in the Carnian rocks of the Western Tethys is lower than that measured in some modern sediments $^{33}$ (average $\mathrm{Hg}=\mathrm{ca} .40-60 \mathrm{ppb}$ ) and in clastic rocks covering other Phanerozoic events linked to major volcanic activity ${ }^{28}$ (average $\mathrm{Hg}=62.4 \mathrm{ppb}$ ), but is closer to the average $\mathrm{Hg}$ concentrations found in limestones across the same Phanerozoic events ${ }^{28}$ (average $\mathrm{Hg}=34.3 \mathrm{ppb}$ ). All $\mathrm{Hg}$ and TOC results are in the Supplementary Tables S1-S4and Supplementary Figures S1-S4.

Low $\mathrm{Hg}$ concentrations are also coupled to generally low TOC values $(<1 \mathrm{wt} \%)$, with only $11 \%$ of all samples showing TOC above $1 \mathrm{wt} \%$ (Fig. 2). Hg/TOC values for TOC $>0.2 \mathrm{wt} \%$, i.e., above the recommended lower limit for TOC normalization ${ }^{28}$, are on average lower (38.2 ppb/wt\%) than those recorded during other Phanerozoic events (average $\mathrm{Hg} / \mathrm{TOC}=71.9 \mathrm{ppb} / \mathrm{wt} \%$ ) linked to major volcanic activity, although most among them are linked to subaerial rather than submarine LIPs $^{28}$. 


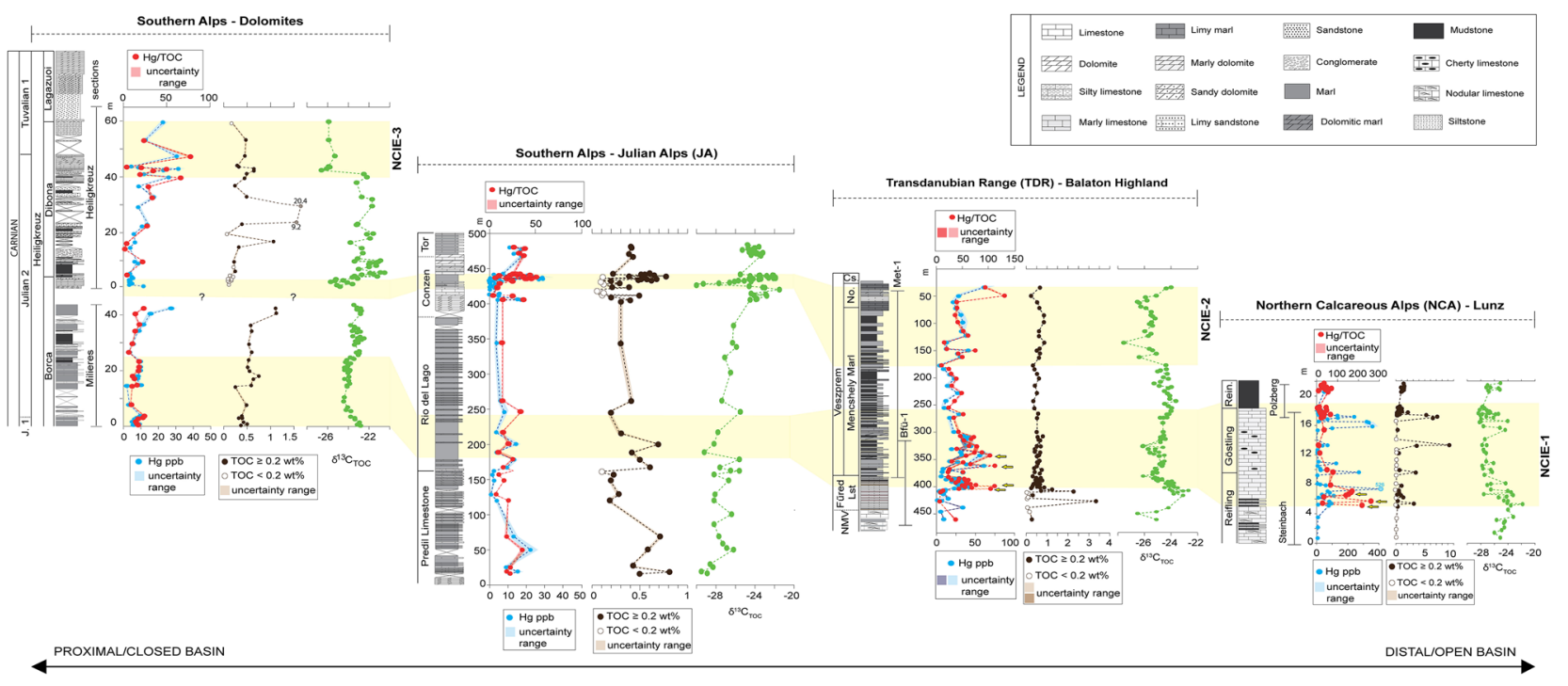

Figure 3. $\mathrm{Hg}, \mathrm{Hg} / \mathrm{TOC}$, and C-isotope data from the Western Tethys. Hg has been normalized for TOC $>0.2 \mathrm{wt} \%$ (Fig. 2). C isotope data and stratigraphic correlations are from ref. ${ }^{6-8}$. The $10 \% \mathrm{Hg}$ concentration uncertainty is indicated on each $\mathrm{Hg}$ data plot in the form of shaded, semitransparent bounds; the $\pm 0.02 \mathrm{wt} \%$ uncertainty on TOC measurements is also shown by semitransparent bounds; and the uncertainty envelope for each $\mathrm{Hg} / \mathrm{TOC}$ value is shown on each $\mathrm{Hg} / \mathrm{TOC}$ plot by a pale red field. Note that the TOC uncertainty bounds are visible only for section Julian Alps (JA) at this scale. The yellow arrows indicate the onset of $\mathrm{Hg} / \mathrm{TOC}$ peaks in the NCA and TDR before and through the facies change.

In the composite section of the Dolomites, the Hg concentrations are very low (Supplementary Table S1 and Fig. S1; Fig. 3), with a maximum value of $33 \mathrm{ppb}$ and an average of $9.2 \mathrm{ppb}$. Hg only shows a slight increase (from 6.5 to $27 \mathrm{ppb}$ ) in the upper part of the section (the upper Dibona Member of the Heiligkreuz Formation) and reaches its maximum value (33 ppb) at 40-50 m, within the NCIE-3 (Fig. 3). TOC values range from 0.1 to $20.5 \mathrm{wt} \%$. Two high TOC of $9.2 \mathrm{wt} \%$. and $20.4 \mathrm{wt} \%$ are linked to the presence of abundant wood particles, as observable in these rock samples simply by eye. In the upper part of the section (40-60 m, NCIE-3), an increase in $\mathrm{Hg} / \mathrm{TOC}$ to $>20 \mathrm{ppb} / \mathrm{wt} \%$ is recorded at the NCIE-3 and is parallel to the rise in $\mathrm{Hg}$ concentrations (Fig. 3).

The $\mathrm{Hg}$ concentrations of the samples from the Julian Alps are low (Supplementary Table S2 and Fig. S2; Fig. 2), with a maximum value of $27 \mathrm{ppb}$ and an average of $10 \mathrm{ppb}$. TOC is also low, with values ranging from 0.2 to $0.8 \mathrm{wt} \%$. Just before and at the end of the NCIE-2, $\mathrm{Hg}$ and $\mathrm{Hg} / \mathrm{TOC}$ values show three- to sixfold increases in the samples from the Julian Alps, as $\mathrm{Hg}$ values rise from < $5 \mathrm{ppb}$ up to $30 \mathrm{ppb}$ and $\mathrm{Hg} / \mathrm{TOC}$ from ca. $14 \mathrm{ppb} /$ wt $\%$ up to a maximum of $49 \mathrm{ppb} / \mathrm{wt} \%$ (from 435 to $440 \mathrm{~m}$ ) (Fig. 3).

$\mathrm{Hg}$ values through the Balaton Highland boreholes of the Transdanubian Range show a maximum value of $61 \mathrm{ppb}$ (Supplementary Table S3 and Fig. S3) with an average of $25.5 \mathrm{ppb}$ (Fig. 2). A sharp Hg increase (from 5.7 to $61 \mathrm{ppb}$ ) is recorded in the upper Füred Limestone and the base of Mencshely Marl Member of Veszprem Formation (from 400 to $340 \mathrm{~m}$ ) where the NCIE-1 starts (Fig. 3). Most of the TOC data are below $1 \mathrm{wt} \%$. $\mathrm{Hg} /$ TOC shows a major increase (from 9.5 to $113 \mathrm{ppb} / \mathrm{wt} \%$ ) at the onset of the NCIE-1 (between 400 to 340 m; Fig. 3).

In the Lunz composite section of the Northern Calcareous Alps, the Hg concentrations vary from 2 to $526 \mathrm{ppb}$ (Supplementary Table S4 and Fig. S4), with most of the data lower than $150 \mathrm{ppb}$. A sharp increase in $\mathrm{Hg}$ is observed from $7 \mathrm{ppb}$ in the lowermost part of the Reifling Formation (at $3.5 \mathrm{~m}$ ) to $78 \mathrm{ppb}$ in the upper part of Reifling Formation (at $5 \mathrm{~m}$ ), where the onset of the NCIE-1 is recorded (Fig. 3). Hg reaches a maximum value (526 ppb) in the uppermost Reifling Formation. At the start of the Göstling Member (onset of CPE at Julian 1-Julian 2 boundary) at $9.6 \mathrm{~m}$, the third increase of $\mathrm{Hg}$ (from 4.3 to $274 \mathrm{ppb}$ ) is recorded. Throughout the Göstling Member, sporadic sharp increases of $\operatorname{Hg}(127,358$, and $240 \mathrm{ppb}$ at 10.8, 15.8, and $17 \mathrm{~m}$, respectively) are observed (Fig. 3). TOC content varies from 0.2 to $9.3 \mathrm{wt} \%$, with most of the values below $2.5 \mathrm{wt} \%$. The $\mathrm{Hg} / \mathrm{TOC}$ is consistently lower than the average value (average $~ 55 \mathrm{ppb} / \mathrm{wt} \%$ in $\mathrm{Hg} / \mathrm{TOC}$ ratios with TOC $>0.2$ ) with major spikes in the uppermost parts of Reifling Formation (from 5 to $10 \mathrm{~m}$ ) coincident with the start of the NCIE-1 (Fig. 3). Notably, the very high $\mathrm{Hg}$ values (>300 ppb, with a max of $526 \mathrm{ppb}$ ) occurring within the Göstling Member are associated with too low TOC $(<0.2 \mathrm{wt} \%)$ for reliable normalization (see Supplementary Fig. S4).

\section{Discussion}

In modern and ancient sediments $\mathrm{Hg}$ tends to be preferentially bound to organic matter, and for this reason $\mathrm{Hg}$ is generally normalized to TOC content ${ }^{28,33}$. In the studied successions, $\mathrm{Hg}$ and $\mathrm{Hg} / \mathrm{TOC}$ overall show similar trends and peaks (Fig. 3), suggesting that higher $\mathrm{Hg}$ deposition is not predominantly controlled by variations in TOC content. TOC concentrations are generally low and fall within a narrow range of values (Fig. 2), making it challenging to evaluate the exact relationships between $\mathrm{Hg}$ and TOC through the different sample sets.

Particular environmental and depositional conditions can enhance local drawdown of $\mathrm{Hg}$ and its accumulation in sediments without the need for an actual net increase of atmospheric Hg input (e.g., ref. ${ }^{33}$ ). Marine redox 
chemistry is a controlling factor in Hg burial. For example, the development of strong euxinic (free sulfide) conditions may lead to enhanced pyrite formation, which may facilitate $\mathrm{Hg}$ deposition ${ }^{29,33-35}$. However, the samples analysed here are all similar mudstones, thus excluding a lithological control (e.g., limestone $v s$ clastic) on $\mathrm{Hg}$ concentration ${ }^{26,36}$. A small number of marl samples from the Northern Calcareous Alps have very high $\mathrm{Hg}$ concentrations and relatively low TOC values (Figs. 2 and 3), which could indicate the presence of $\mathrm{Hg}$ bound to other sulfide-mineral phases, e.g., pyrite ${ }^{30}$. Nevertheless, in the Northern Calcareous Alps-and also in all the other studied basins-there is evidence against (semi-)permanent euxinic conditions (which would promote $\mathrm{Hg}$ being hosted in sulfides ${ }^{29,33}$ ), for example, the presence of bioturbation and benthic fauna (Halobia and benthic foraminifera ${ }^{37}$ ) in the same strata that record the Hg spikes.

A general shift in basin-wide depositional style, from carbonate-dominated to mainly terrigenous sedimentation, is observed in the Northern Calcareous Alps and Transdanubian Range at the onset of the CPE that followed the initial C-isotope perturbations. This is related to increased continental runoff driven by an enhancement of the hydrological cycle ${ }^{7}$, but we note that the Hg/TOC peaks in the Northern Calcareous Alps and Transdanubian Range start before and continue through the facies change (Fig. 3). In the Transdanubian Range, this sedimentological change was also accompanied by a change in clay mineralogy, with the increase of kaolinite in the Veszprém Marls ${ }^{38}$. $\mathrm{Hg}$ can be captured by clay minerals, as observed across the CretaceousPalaeogene boundary and the Toarcian $\mathrm{OAE}^{26}$. However, in the Carnian sequences, the $\mathrm{Hg}$ (and $\mathrm{Hg} / \mathrm{TOC}$ ) starts to rise before the change in clay mineralogy, and published $\mathrm{Al}$ concentrations measured on the same samples from MET-1 core ${ }^{22}$ show no relation to $\mathrm{Hg}$ (Supplementary Figure S3). Hence, although part of the Hg could be hosted in other, still unidentified minerals, the absence of euxinic facies and changes in clay mineralogy directly correlated to $\mathrm{Hg}$ variations suggest that in the studied basins $\mathrm{Hg}$ is preferentially hosted in organic matter, as in the majority of modern and ancient sediments ${ }^{28,33}$.

Differences in position, $\mathrm{Hg}$ concentrations and magnitude of the $\mathrm{Hg} / \mathrm{TOC}$ spikes are observed between basins. In the Northern Calcareous Alps and the Transdanubian Range, a substantial rise of $\mathrm{Hg} / \mathrm{TOC}$ is recorded at the onset of the NCIE-1, while in the Southern Alps a Hg/TOC increase is not apparent in the same stratigraphic interval (Fig. 3). Subsequent Hg/TOC increases occur during NCIE-2 in the Transdanubian Range and the Julian Alps, and during NCIE-3 in the Dolomites (Fig. 3). Collectively, this suggests that in the western Tethys Hg/ TOC increased during the early stages of NCIE-1 in the Northern Calcareous Alps and Transdanubian Range, just before and during the late stage of NCIE-2 in the Julian Alps and Transdanubian Range, and in the early stages of NCIE-3 in the Dolomites.

Different $\mathrm{Hg}$ and $\mathrm{Hg} / \mathrm{TOC}$ signals could arise due to local differential diagenesis, as intense weathering and post-depositional oxidation of organic matter can change $\mathrm{Hg}$ concentrations in sediments and $\mathrm{Hg} / \mathrm{TOC}$ values $^{30,39}$. Enrichments in $\mathrm{Hg}$ and $\mathrm{Hg} / \mathrm{TOC}$ may be controlled by early diagenetic degradation of organic matter, potentially amplifying the $\mathrm{Hg} / \mathrm{TOC}$ ratios, especially in samples with very low $\mathrm{TOC}^{40}$. The detected $\mathrm{Hg} /$ TOC spikes are in samples with TOC content $\geq 0.2 \mathrm{wt} \%$ and parallel enrichments in absolute Hg concentrations (Fig. 3). Moreover, previous biomarker and pyrolysis analyses, clay mineralogy, colour alteration index of conodont apatite, and sporomorphs coloration indicate immature to low thermal maturity for the analysed samples in the Southern Alps, Transdanubian Range, and Northern Calcareous Alps $s^{6,8,19,38}$. Therefore, we find it unlikely that degradation of organic matter was responsible for the $\mathrm{Hg} / \mathrm{TOC}$ signal, and we conclude that the observed anomalies in both $\mathrm{Hg}$ and $\mathrm{Hg} / \mathrm{TOC}$ across different basins, likely record actual changes in $\mathrm{Hg}$ input into the depositional environment, and not local changes in $\mathrm{Hg}$ drawdown and/or diagenesis.

The terrestrial $\mathrm{Hg}$ reservoir can modulate global marine $\mathrm{Hg}$ deposition ${ }^{30,31}$. As one of the main reservoirs of the exogenic Hg cycle, soil erosion and oxidation of terrestrial organic matter following extensive collapse of vegetation on land can result in an increase of $\mathrm{Hg}$ input into the marine depositional environments ${ }^{33}$. However, there is no evidence for such modulation during the CPE. The Carnian marks the formation of thick productive coal measures after a global "coal gap" that started at the Permian-Triassic Mass Extinction ${ }^{41}$, and witnessed the appearance and spread of many new land plant groups ${ }^{9}$ and the extensive development of soils in the Western Tethys $^{42,43}$, suggesting an overall expansion of flora rather than a collapse.

An enhanced hydrological cycle during the CPE resulted in the expansion of large riverine systems in Pangea ${ }^{9,44,45}$ and consequent increases of terrigenous inputs in many basins, where these spikes of continental runoff are the distinctive signature of the $\mathrm{CPE}$. The transport of terrestrial material into the basins could increase $\mathrm{Hg}$ concentrations in marine sediments. However, higher $\mathrm{Hg}$ concentrations and $\mathrm{Hg} / \mathrm{TOC}$ are recorded just before, at the onset, and during the NCIEs, which all precede siliciclastic inputs ${ }^{7}$. As discussed above, in the Northern Calcareous Alps (Lunz) and in the Transdanubian Range (Balatonfüred) Hg and Hg/TOC start to increase at the onset of the NCIE, before the $\delta^{13} \mathrm{C}_{\mathrm{TOC}}$ reaches its minimum values, while the subsequent increases occur during NCIE-2 in the Transdanubian Range, just before and at the end of NCIE-2 in the Julian Alps as well as early stages of NCIE-3 in the Dolomites. This implies that the episodic enhancement of continental runoff was not responsible for the initial, pre-NCIEs increases of $\mathrm{Hg}$ loading into the basins. However, the increased siliciclastic input that followed the initial $\mathrm{Hg}$ and NCIE onset, could have resulted in the transport of additional $\mathrm{Hg}$ in later stages of the NCIEs intervals (e.g., increases of $\mathrm{Hg}$ at the end of the NCIE-2 in the Julian Alps).

A huge amount of $\mathrm{Hg}$ was plausibly released by the Carnian Wrangellia oceanic plateau at the time of the CPE. Given the temporal overlap between Wrangellia LIP and the CPE, substantiated by biostratigraphic, radioisotopic, and geochemical data ${ }^{9,16,25,46}$, and in the absence of clear evidence for other dominant $\mathrm{Hg}$ drawdown and transport mechanisms, it is plausible to assume a volcanic origin of the additional Hg during the CPE. Wrangellia erupted a minimum of $1 \times 10^{6} \mathrm{~km}^{3}$ of basalts onto the Panthalassa ocean floor (Fig. 1) at a latitude of about $10-15^{\circ} \mathrm{N}^{16,18}$. The remnants of Wrangellia now outcrop in northwestern America, but coeval oceanic intraplate basalts are also present in east Asia (Sambosan and Taukha belts), which could have been part of the same LIP ${ }^{16}$. Os isotope data from pelagic successions of Japan show a sharp ${ }^{187} \mathrm{Os} /{ }^{188} \mathrm{Os}$ increase in the Julian (Fig. 4), that is interpreted as unradiogenic Os input from Wrangellia emplacement ${ }^{16}$. 


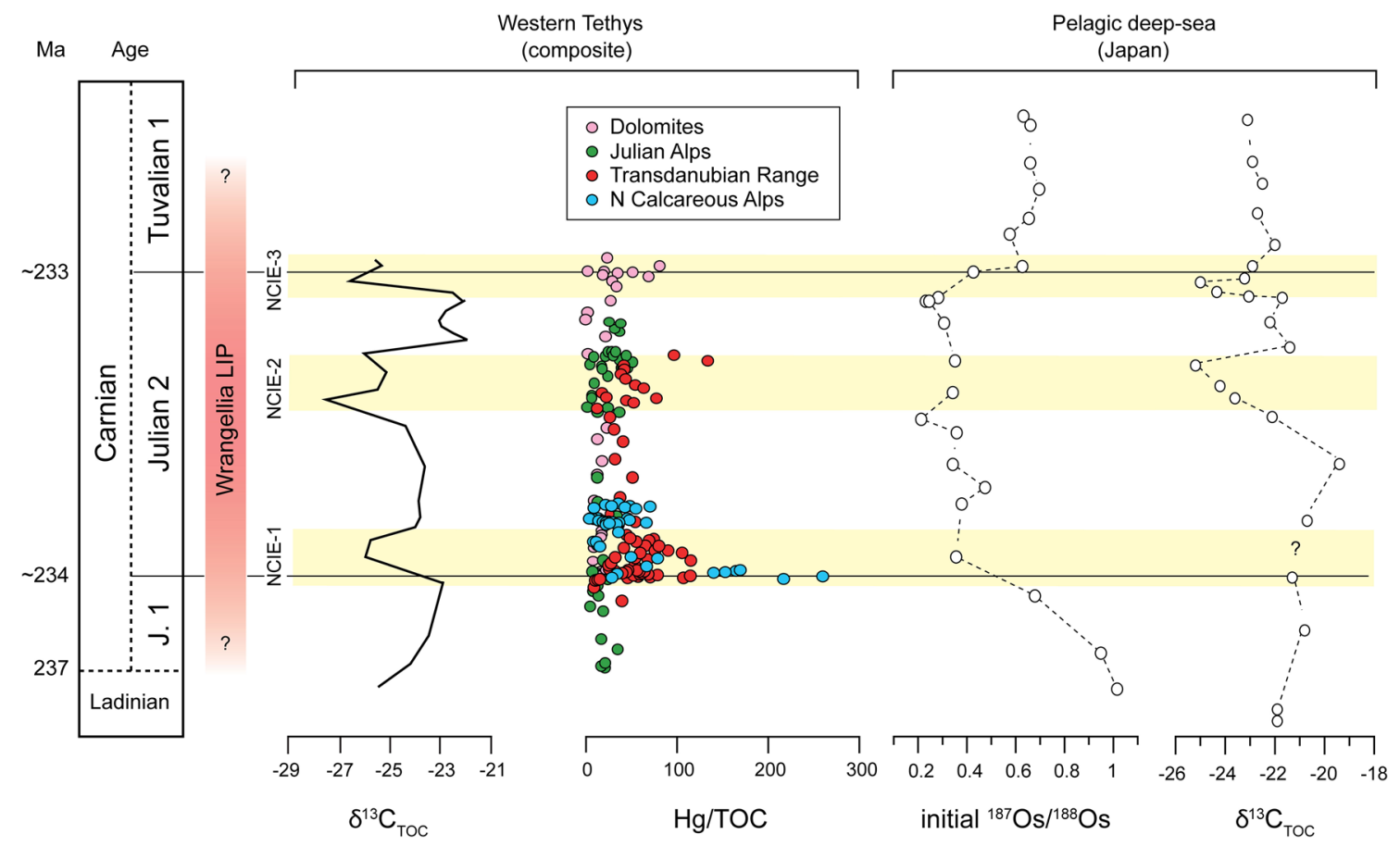

Figure 4. A comparison of our Western Tethys composite Hg/TOC stratigraphy with Os-isotopes through the same period associated with the Carnian Pluvial Episode recorded in Japan. Os and C-isotope data from Panthalassa are from ref. ${ }^{16}$. C-isotope data from the Western Tethys are from ref. ${ }^{8}$. The approximate period of the Wrangellia LIP emplacement is taken from refs. ${ }^{6,8,9,14,16,25,48}$.

As with other similar oceanic plateaus ${ }^{26,36}$, dispersal of $\mathrm{Hg}$ during the initial submarine phase of Wrangellia was likely predominantly marine. Current evidence suggests that $\mathrm{Hg}$ records across events coeval to the emplacement of LIPs with submarine or mixed submarine/subaerial activity, show less consistent $\mathrm{Hg}$ perturbations than those across events coeval with subaerial continental LIPs (e.g., the Siberian Traps), i.e., with atmospheric Hg dispersal ${ }^{26}$. The amplified $\mathrm{Hg}$ signal associated with continental flood basalts may in part result from volcanic intrusions into sedimentary sequences, with coals and evaporites ${ }^{47}$. This potentially liberates a large quantity of previously bound $\mathrm{Hg}$ through melting and combustion ${ }^{48}$, adding to the simpler magmatic degassing thought to dominate $\mathrm{Hg}$ release from oceanic igneous plateaus. Moreover, the oceanic residence time of $\mathrm{Hg}$ is shorter ( $<1000$ years) than the mixing time, whilst in the atmosphere $\mathrm{Hg}$ in the vapor phase has a relatively longer residence time (0.5-2 years) compared to the mixing time and atmospheric $\mathrm{Hg}$ can thus be potentially dispersed globally in contrast to more localised dispersion for oceanic $\mathrm{Hg}^{49}$. As a result, $\mathrm{Hg}$ emitted from submarine volcanism is expected to be less efficiently and uniformly dispersed than atmospheric $\mathrm{Hg}^{26,36}$. Indeed, the magnitudes of the Hg/TOC peaks at events coeval with submarine LIPs (e.g., OAE 1a, OAE 1b, OAE 2) tend to be smaller (up to $200 \mathrm{ppb} / \mathrm{wt} \%$ ) $^{26,28,36,50,51}$ compared to those associated with continental explosive LIPs (e.g., up to $600 \mathrm{ppb} / \mathrm{wt} \%$ for the Siberian Traps $)^{29}$. These lower magnitudes are comparable to the Hg/TOC peaks found in the Carnian (Figs. 3, 4). Hence, differential Hg and Hg/TOC signals in the different studied basins of the Western Tethys might be related to Wrangellia volcanic style, resulting in a less efficient distribution of Hg in different depositional settings. It might be hypothesized that the semi-restricted basins of the Southern Alps limited direct $\mathrm{Hg}$ marine influx to these basins, in contrast to the more open marine settings of the Northern Calcareous Alps and Transdanubian Range (Fig. 1). It is known that the Wrangellia switched between submarine and subaerial activity ${ }^{9}$. The switch in eruptive style to subaerial ${ }^{52}$ has not been dated yet ${ }^{9}$, but may have resulted in a wider atmospheric $\mathrm{Hg}$ dispersal, and anomalous $\mathrm{Hg} / \mathrm{TOC}$ in a wider variety of continental to marine environments ${ }^{26}$.

Alternatively, the lack of a Hg enrichments at the NCIE-1 in the Dolomites and Julian Alps could be explained by stratigraphic features and sampling resolution (Fig. 5). At Milieres-Dibona section (Dolomites), the onset of the NCIE- 1 could be missing as the sediments below the isotope anomaly do not outcrop in the area (see ref. $^{7}$ ). This is due to the fact that the uppermost San Cassiano-lowermost Heiligkreuz basinal succession of the Dolomites is represented by fine-grained shales that are easily eroded and covered by vegetation. We therefore cannot exclude the possibility that the covered sediments at the base of the section might have prevented sampling of the first $\mathrm{Hg}$ spike, and the onset of NCIE- ${ }^{7}$. In the Julian Alps, the temporal and stratigraphic sampling resolution across NCIE- 1 is limited because the sections are extremely expanded, almost vertical and poorly accessible. Here, the NCIE- 1 is captured by only 4 samples, and so only these few samples were measured to assess $\mathrm{Hg}$ across NCIE-1, out of a total of $\sim 70 \mathrm{~m}$ of the succession. As observed in the Transdanubian Range and Northern Calcareous Alps, Hg/TOC are not constant within the body of the NCIE-1, and the short-lived spikes may have been missed in the Julian Alps (Fig. 5). 


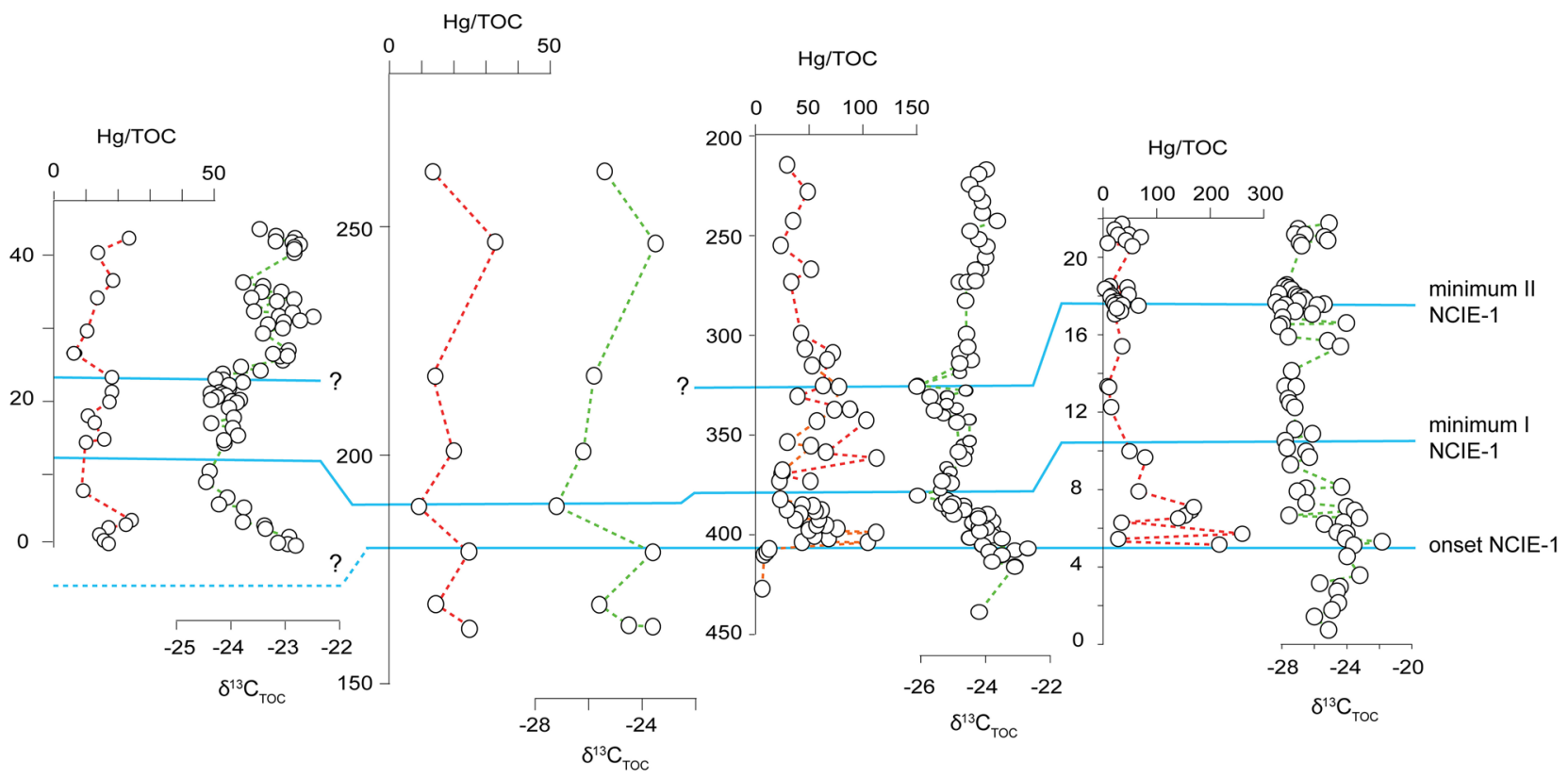

Figure 5. Detail of $\mathrm{Hg} / \mathrm{TOC}$ and $\delta^{13} \mathrm{C}_{\mathrm{TOC}}$ data across the NCIE- 1 in the studied basins of the Western Tethys. The Hg/TOC spike associated with the NCIE- 1 of the CPE could be missing in the Southern Alps (Dolomites and Julian Alps) because of the incompleteness of the succession and lower sampling resolution.

\section{Conclusions}

Our new data show pulses of increased Hg loading in the Western Tethys during the early Late Triassic CPE. Although muted compared to other examples in the geological record, these pulses occur in correspondence to NCIEs and we note that the $\mathrm{Hg} / \mathrm{TOC}$ record is different in different basins. A rise of $\mathrm{Hg} / \mathrm{TOC}$ is recorded in the more open, and complete basin successions of the Northern Calcareous Alps (Austria) and the Transdanubian Range (Hungary) at the onset of the first NCIE of the CPE, but the same spike is not recorded during the same interval in the more restricted basins of the Southern Alps (Italy). This geographical distribution might be an artifact of incomplete sections or low temporal sampling resolution. However, it is also consistent with a primary signal as major interbasinal differences in $\mathrm{Hg}$ concentrations and $\mathrm{Hg} / \mathrm{TOC}$ are recorded during other Mesozoic LIP events linked to emplacements of oceanic plateaux, and are explained by the relatively inefficient dispersal of $\mathrm{Hg}$ from submarine volcanism ${ }^{26,27,53}$. Overall, our data is consistent with the hypothesis that pulses of Wrangellia volcanic activity triggered multiple injections of isotopically light $\mathrm{C}$ into the atmosphere-ocean system that led to associated environmental perturbations.

\section{Methods}

Hg analysis. A total of 243 samples were analysed for $\mathrm{Hg}$ concentrations using a Lumex RA-915 Portable Mercury Analyser with PYRO-915 Pyrolyzer at the University of Oxford, using the method described by ref. 54. Samples were powdered with an agate mortar, then an aliquot of 50-250 mg was weighed into a glass boat before being placed into the pyrolyzer and heated to $700^{\circ} \mathrm{C}$. Volatilized elementary $\mathrm{Hg}$ was quantified via atomic absorption spectrometry. At the start of each run and throughout the measurement sequences (every 10 samples), paint-contaminated soil (NIST 2587; $290 \mathrm{ppb} \mathrm{Hg}$ ) standards were analysed, using masses ranging from 10 to $90 \mathrm{mg}$, to calibrate the Lumex. The analysed standards indicate reproducibility was generally better than $10 \%$ for $\mathrm{Hg}$ concentrations. TOC normalization of $\mathrm{Hg}$ was applied when $\mathrm{TOC}$ was above or equal to $0.2 \%$ following the approach recommended by ref. ${ }^{28}$. For the Transdanubian Range $\mathrm{Hg} / \mathrm{Al}$ has been calculated using published elemental data of ref. ${ }^{22}$, which were measured on the same core material. The $\mathrm{Hg}$ data are coupled to the organic carbon $\delta^{13} \mathrm{C}$ data previously generated on the same samples ${ }^{7,8}$.

Analysis of total organic carbon (TOC). An Elementar Soli TOC Cube was used to determine Total Organic Carbon (TOC) in rock samples at the University of Ferrara. The analyser is equipped with two combustion units: a dynamic heater able to raise the temperature from ambient to $900{ }^{\circ} \mathrm{C}$ and a post-combustion zone kept at a constant temperature of $800{ }^{\circ} \mathrm{C}$, containing a platinum catalyst to achieve complete oxidation of all combustion products released by the dynamic heater. Combustion takes place in pure oxygen at a flow rate of $150 \mathrm{ml} / \mathrm{min}$. An infrared detector detects the formed $\mathrm{CO}_{2}$. About $500 \mathrm{mg}$ of each sample were weighed into stainless steel crucibles that were heated prior to analysis to avoid contamination by $\mathrm{C}$ residues. Values are reported as the mean of duplicate analysis. The sample weight depended on the $\mathrm{C}$ content and could be extended up to $1 \mathrm{~g}$ in cases where the $\mathrm{C}$ contents were low (equal or below $0.1 \mathrm{wt} \%$ ). A standard of calcium carbonate $\left(\mathrm{CaCO}_{3}\right.$, Calciumcarbonat, Elementar $)$ and a soil standard $\left(\mathrm{CaCO}_{3}\right.$, Bodenstandard, Elementar with approxi- 
mately $1.3 \% \mathrm{C}$ content) were analysed prior, between, and after each run. Temperature-dependent differentiation of total carbon (DIN19539) has been applied for determining the total organic carbon content as described by ref. ${ }^{55}$. The dynamic temperature ramping method starts at about $100{ }^{\circ} \mathrm{C}$. After introducing the sample, the temperature is increased at a rate of $90^{\circ} \mathrm{C} / \mathrm{min}$ up to $600^{\circ} \mathrm{C}$ for the determination of TOC. The average standard deviation (SD), based on replicate analyses of nine samples and a soil standard (Bodenstandard), was $\pm 0.02 \mathrm{wt} \%$.

Received: 2 June 2021; Accepted: 13 August 2021

Published online: 30 August 2021

\section{References}

1. Schlager, W. \& Schöllnberger, W. Das Prinzip stratigraphischer Wenden in der Schichtfolge der Nördlichen Kalkalpen. Mitteilungen der Geol. Gesellschaft Wien 66-67, 165-193 (1974).

2. Simms, M. J. \& Ruffell, A. H. Synchroneity of climatic change and extinctions in the Late Triassic. Geology 17, 265-268 (1989).

3. Mancuso, A. C., Benavente, C. A., Irmis, R. B. \& Mundil, R. Evidence for the Carnian Pluvial Episode in Gondwana: New multiproxy climate records and their bearing on early dinosaur diversification. Gondwana Res. 86, 104-125 (2020).

4. Simms, M. J. \& Ruffell, A. H. Climatic and biotic change in the late Triassic. J. Geol. Soc. 147, 321-327 (1990).

5. Hornung, T. \& Brandner, R. Biochronostratigraphy of the Reingraben Turnover (Hallstatt Facies Belt): Local black shale events controlled by regional tectonics, climatic change and plate tectonics. Facies 51, 460-479 (2005).

6. Dal Corso, J. et al. Discovery of a major negative $\delta 13 \mathrm{C}$ spike in the Carnian (Late Triassic) linked to the eruption of Wrangellia flood basalts. Geology 40, 79-82 (2012).

7. Dal Corso, J. et al. Carbon isotope records reveal synchronicity between carbon cycle perturbation and the 'Carnian Pluvial Event' in the Tethys realm (Late Triassic). Glob. Planet. Change 127, 79-90 (2015).

8. Dal Corso, J. et al. Multiple negative carbon-isotope excursions during the Carnian Pluvial Episode (Late Triassic). Earth Sci. Rev. 185, 732-750 (2018)

9. Dal Corso, J. et al. Extinction and dawn of the modern world in the Carnian (Late Triassic). Sci. Adv. 6, eaba0099 (2020).

10. Trotter, J. A., Williams, I. S., Nicora, A., Mazza, M. \& Rigo, M. Long-term cycles of Triassic climate change: A new $\delta 18 \mathrm{O}$ record from conodont apatite. Earth Planet. Sci. Lett. 415, 165-174 (2015).

11. Ruffell, A., Simms, M. J. \& Wignall, P. B. The Carnian Humid Episode of the late Triassic: A review. Geol. Mag. 153, 271-284 (2016).

12. Zhang, Y. et al. Cycle-calibrated magnetostratigraphy of middle Carnian from South China: Implications for Late Triassic time scale and termination of the Yangtze Platform. Palaeogeogr. Palaeoclimatol. Palaeoecol. 436, 135-166 (2015).

13. Miller, C. S. et al. Astronomical age constraints and extinction mechanisms of the Late Triassic Carnian crisis. Sci. Rep. 7, 1-7 (2017).

14. Bernardi, M., Gianolla, P., Petti, F. M., Mietto, P. \& Benton, M. J. Dinosaur diversification linked with the Carnian Pluvial Episode. Nat. Commun. 9, 1 (2018).

15. Fu, X. et al. A possible link between the Carnian Pluvial Event, global carbon-cycle perturbation, and volcanism: New data from the Qinghai-Tibet Plateau. Glob. Planet. Change 194, 103300 (2020).

16. Tomimatsu, Y. et al. Marine osmium isotope record during the Carnian "pluvial episode" (Late Triassic) in the pelagic Panthalassa Ocean. Glob. Planet. Change 197, 103387 (2021).

17. Sun, Y. D. et al. Climate warming, euxinia and carbon isotope perturbations during the Carnian (Triassic) Crisis in South China. Earth Planet. Sci. Lett. 444, 88-100 (2016).

18. Sun, Y. D., Richoz, S., Krystyn, L., Zhang, Z. T. \& Joachimski, M. M. Perturbations in the carbon cycle during the carnian humid episode: Carbonate carbon isotope records from southwestern China and Northern Oman. J. Geol. Soc. Lond. 176, 167-177 (2019).

19. Mueller, S., Krystyn, L. \& Kürschner, W. M. Climate variability during the Carnian Pluvial Phase - A quantitative palynological study of the Carnian sedimentary succession at Lunz am See, Northern Calcareous Alps, Austria. Palaeogeogr. Palaeoclimatol. Palaeoecol. 441, 198-211 (2016).

20. Mueller, S., Hounslow, M. W. \& Kürschner, W. M. Integrated stratigraphy and palaeoclimate history of the Carnian Pluvial event in the Boreal realm; new data from the upper triassic kapp toscana group in central Spitsbergen (Norway). J. Geol. Soc. Lond. 173, 186-202 (2016).

21. Jin, X. et al. The aftermath of the CPE and the Carnian-Norian transition in northwestern Sichuan basin, South China. J. Geol. Soc. Lond. 176, 179-196 (2019).

22. Baranyi, V., Miller, C. S., Ruffell, A., Hounslow, M. W. \& Kürschner, W. M. A continental record of the carnian pluvial episode (CPE) from the mercia mudstone group (UK): Palynology and climatic implications. J. Geol. Soc. Lond. 176, 149-166 (2019).

23. Hornung, T., Krystyn, L. \& Brandner, R. A Tethys-wide mid-Carnian (Upper Triassic) carbonate productivity crisis: Evidence for the Alpine Reingraben Event from Spiti (Indian Himalaya)?. J. Asian Earth Sci. 30, 285-302 (2007).

24. Gattolin, G. et al. Sequence stratigraphy after the demise of a high-relief carbonate platform (Carnian of the Dolomites): Sea-level and climate disentangled. Palaeogeogr. Palaeoclimatol. Palaeoecol. 423, 1-17 (2015).

25. Furin, S. et al. High-precision U-Pb zircon age from the Triassic of Italy: Implications for the Triassic time scale and the Carnian origin of calcareous nannoplankton and dinosaurs. Geology 34, 1009-1012 (2006).

26. Percival, L. M. E. et al. Does large igneous province volcanism always perturb the mercury cycle? Comparing the records of Oceanic Anoxic Event 2 and the end-cretaceous to other Mesozoic events. Am. J. Sci. 318, 799-860 (2018).

27. Lindström, S. et al. Volcanic mercury and mutagenesis in land plants during the end-Triassic mass extinction. Sci. Adv. 5, eaaw4018 (2019).

28. Grasby, S. E., Them, T. R., Chen, Z., Yin, R. \& Ardakani, O. H. Mercury as a proxy for volcanic emissions in the geologic record. Earth-Sci. Rev. 196, 102880 (2019).

29. Sanei, H., Grasby, S. E. \& Beauchamp, B. Latest permian mercury anomalies. Geology 40, 63-66 (2012).

30. Them, T. R. et al. Terrestrial sources as the primary delivery mechanism of mercury to the oceans across the Toarcian Oceanic Anoxic Event (Early Jurassic). Earth Planet. Sci. Lett. 507, 62-72 (2019).

31. Dal Corso, J. et al. Permo-Triassic boundary carbon and mercury cycling linked to terrestrial ecosystem collapse. Nat. Commun. 11, 2962 (2020).

32. Roghi, G., Gianolla, P., Minarelli, L., Pilati, C. \& Preto, N. Palynological correlation of Carnian humid pulses throughout western Tethys. Palaeogeogr. Palaeoclimatol. Palaeoecol. 290, 89-106 (2010).

33. Shen, J. et al. Sedimentary host phases of mercury $(\mathrm{Hg})$ and implications for use of $\mathrm{Hg}$ as a volcanic proxy. Earth Planet. Sci. Lett. 543, 11633 (2020).

34. Benoit, J. M., Gilmour, C. C., Mason, R. P. \& Heyes, A. Sulfide controls on mercury speciation and bioavailability to methylating bacteria in sediment pore waters. Environ. Sci. Technol. 33, 951-957 (1999). 
35. Niessen, S. et al. Influence of sulphur cycle on mercury methylation in estuarine sediment (Seine estuary, France). J. Phys. IV JP 107, 953-956 (2003).

36. Scaife, J. D. et al. Sedimentary mercury enrichments as a marker for submarine large igneous province volcanism? Evidence from the mid-cenomanian event and oceanic anoxic event 2 (Late Cretaceous). Geochem. Geophys. Geosyst. 18, 4253-4275 (2017).

37. Tollmann, A. Analyse des klassischen nordalpinen Mesozoikums: Stratigraphie, Fauna und Fazies der Nördlichen Kalkalpen. (Deuticke Wien, 1976).

38. Rostási, Á., Raucsik, B. \& Varga, A. Palaeoenvironmental controls on the clay mineralogy of Carnian sections from the Transdanubian Range (Hungary). Palaeogeogr. Palaeoclimatol. Palaeoecol. 300, 101-112 (2011).

39. Charbonnier, G., Adatte, T., Föllmi, K. B. \& Suan, G. Effect of intense weathering and postdepositional degradation of organic matter on Hg/TOC proxy in organic-rich sediments and its implicationsfor deep-time investigations. Geochem. Geophys. Geosyst. 21, 2019 (2020).

40. Jones, D. S., Martini, A. M., Fike, D. A. \& Kaiho, K. A volcanic trigger for the late ordovician mass extinction? Mercury data from south china and laurentia. Geology 45, 631-634 (2017).

41. Retallack, G. J., Veevers, J. J. \& Morante, R. Global coal gap between Permian-Triassic extinction and Middle Triassic recovery of peat-forming plants. Bull. Geol. Soc. Am. 108, 195-207 (1996).

42. Gianolla, P., Ragazzi, E. \& Roghi, G. Upper Triassic amber from the Dolomites (Northern Italy). A paleoclimatic indicator? Riv. Ital. di Paleontol. e Stratigr. 104, 381-390 (1998).

43. Preto, N. \& Hinnov, L. A. Unraveling the origin of carbonate platform cyclothems in the Upper Triassic Dürresntein Formation (Dolomites, Italy). J. Sediment. Res. 73, 774-789 (2003).

44. Arche, A. \& López-Gómez, J. The Carnian Pluvial Event in Western Europe: New data from Iberia and correlation with the Western Neotethys and Eastern North America-NW Africa regions. Earth Sci. Rev. 128, 196-231 (2014).

45. Klausen, T. G., Nyberg, B. \& Helland-Hansen, W. The largest delta plain in Earth's history. Geology 47, 470-474 (2019).

46. Greene, A. R. et al. The architecture of oceanic plateaus revealed by the volcanic stratigraphy of the accreted Wrangellia oceanic plateau. Geosphere 6, 47-73 (2010).

47. Svensen, H. et al. Siberian gas venting and the end-Permian environmental crisis. Earth Planet. Sci. Lett. 277, 490-500 (2009).

48. Wang, X. et al. Mercury anomalies across the end Permian mass extinction in South China from shallow and deep water depositional environments. Earth Planet. Sci. Lett. 496, 159-167 (2018).

49. Schroeder, W. H. \& Munthe, J. Atmospheric mercury - An overview. Atmos. Environ. 32, 809-822 (1998).

50. Charbonnier, G. \& Föllmi, K. B. Mercury enrichments in lower Aptian sediments support the link between Ontong Java large igneous province activity and oceanic anoxic episode 1a. Geology 45, 63-66 (2017).

51. Sabatino, N. et al. Mercury anomalies in upper Aptian-lower Albian sediments from the Tethys realm. Palaeogeogr. Palaeoclimatol. Palaeoecol. 495, 163-170 (2018).

52. Greene, A. R. et al. The architecture of oceanic plateaus revealed by the volcanic stratigraphy of the accreted Wrangellia oceanic plateau. Geosphere 6, 47-73 (2010).

53. Percival, L. M. E. et al. Mercury evidence for pulsed volcanism during the end-Triassic mass extinction. Proc. Natl. Acad. Sci. USA 114, 7929-7934 (2017)

54. Bin, C., Xiaoru, W. \& Lee, F. S. C. Pyrolysis coupled with atomic absorption spectrometry for the determination of mercury in Chinese medicinal materials. Anal. Chim. Acta 447, 161-169 (2001).

55. Natali, C., Bianchini, G. \& Carlino, P. Thermal stability of soil carbon pools: Inferences on soil nature and evolution. Thermochim. Acta 683, 178478 (2020).

\section{Acknowledgements}

We thank G. Roghi, N. Preto, and M. Caggiati for assistance in the field. We acknowledge G. Bianchini, G.M. Salani, and V. Brombin for the help with TOC analysis. M.M.-J. and P.G. acknowledges FAR 2018-2019 founding of the University of Ferrara. T.A.M. and J.F. acknowledge funding from ERC consolidator Grant (ERC2018-COG-818717-V-ECHO). We thank the reviewers and editor for constructive comments that improved the manuscript.

\section{Author contributions}

J.D.C. and P.G. designed the study. P.G. and J.D.C. collected the samples. M.M.-J. prepared the samples. M.M.-J., J.F. and T.M. carried out $\mathrm{Hg}$ analysis. All the authors discussed the data and conclusions of the study. M.M.-J., J.D.C. and P.G. wrote the manuscript with inputs from all co-authors.

\section{Competing interests}

The authors declare no competing interests.

\section{Additional information}

Supplementary Information The online version contains supplementary material available at https://doi.org/ 10.1038/s41598-021-96890-8.

Correspondence and requests for materials should be addressed to M.M.-J. or J.D.C.

Reprints and permissions information is available at www.nature.com/reprints.

Publisher's note Springer Nature remains neutral with regard to jurisdictional claims in published maps and institutional affiliations. 
(c) (i) Open Access This article is licensed under a Creative Commons Attribution 4.0 International cc) License, which permits use, sharing, adaptation, distribution and reproduction in any medium or format, as long as you give appropriate credit to the original author(s) and the source, provide a link to the Creative Commons licence, and indicate if changes were made. The images or other third party material in this article are included in the article's Creative Commons licence, unless indicated otherwise in a credit line to the material. If material is not included in the article's Creative Commons licence and your intended use is not permitted by statutory regulation or exceeds the permitted use, you will need to obtain permission directly from the copyright holder. To view a copy of this licence, visit http://creativecommons.org/licenses/by/4.0/.

(C) The Author(s) 2021 